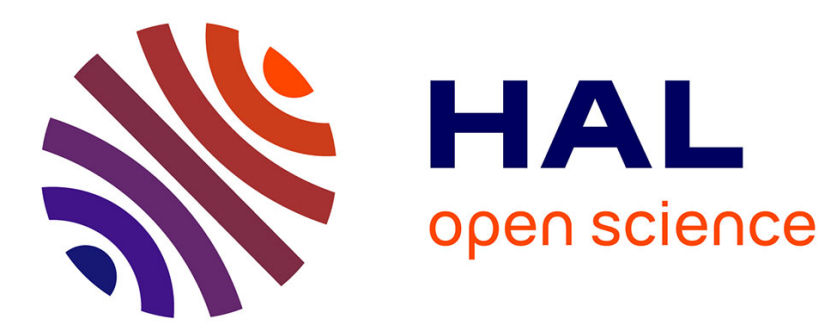

\title{
A Forgotten Second Author: Arthur S. Campbell (1899-1972), Protistologist
}

\author{
John Dolan
}

\section{To cite this version:}

John Dolan. A Forgotten Second Author: Arthur S. Campbell (1899-1972), Protistologist. Protist, 2021, pp.125802. 10.1016/j.protis.2021.125802 . hal-03182652

\section{HAL Id: hal-03182652 \\ https://hal.sorbonne-universite.fr/hal-03182652}

Submitted on 26 Mar 2021

HAL is a multi-disciplinary open access archive for the deposit and dissemination of scientific research documents, whether they are published or not. The documents may come from teaching and research institutions in France or abroad, or from public or private research centers.
L'archive ouverte pluridisciplinaire HAL, est destinée au dépôt et à la diffusion de documents scientifiques de niveau recherche, publiés ou non, émanant des établissements d'enseignement et de recherche français ou étrangers, des laboratoires publics ou privés. 
Dolan, J.R. 2021. A Forgotten Second Author: Arthur S. Campbell (1899-1972), Protistologist, Protist DOI: 0.1016/j.protis.2021.125802

\section{A Forgotten Second Author: Arthur S. Campbell (1899-1972), Protistologist}

John R. Dolan, Sorbonne Université, Laboratoire de Océanographie de Villefranche-sur-Mer, CNRS UMR 7093, Station Zoologique, 06230 Villefranchesur-Mer, France; dolan@obs-vlfr.fr

Keywords: History of Protistology, tintinnid cilates, microfossils, foraminifera, radiolaria

\section{Introduction}

Arthur Shackelton Campbell was an American protistologist active mostly in the first half of the 20th century. To those of us who work on ciliates, he is known as the second author of two classic monographs on tintinnid ciliates with Charles A. Kofoid. To those of us who work on microfossils, or on rhizaria, he is known for some of the first American monographs on fossil radiolarians with Bruce L. Clark, and articles on fossil foraminifera with Joseph A. Cushman, as well as for chapters on fossil radiolaria and tintinnids in Raymond C. Moore's treatise on invertebrate paleontology. Arthur Campbell worked then with major figures of his time, but is little known in his own right. This is perhaps because he worked successively on very different taxa. He began writing as an undergraduate on a variety of invertebrate taxa, then focused on tintinnid ciliates, followed by fossil foraminifera, and finally on fossil radiolarians. Here a summary of his professional life and varied scientific contributions are given.

\section{Biographical Sketch}

A standard biographical account of Arthur Campbell is very difficult to provide. Searches of scientific journals uncovered no memorials. Newspaper archives contained no obituary notices, nor birth, death, or marriage announcements. The lack of newspaper announcements suggests that Campbell's family may have been of modest means. His years of birth and death are given only in information from Saint Mary's College (Moraga, CA, USA) his long-time employer, concerning an annual prize named after Campbell given by the college to the outstanding undergraduate in the School of Science. The years of birth and death are given along with a statement that he taught Zoology from 1926 to 1961. Oddly enough, of the several faculty and staff of Saint Mary's College contacted, none could provide any information on Campbell, despite the fact that a prize is named in honor of him.. We know he was the only child of Mr. and Mrs. H.S. Campbell of San Bernardino (CA, USA) from a newspaper article announcing that Arthur S. Campbell had been awarded a fellowship to pursue a Masters degree at Harvard (Sup Ref: Anon. 1923). We know he was married only from the 
acknowledgements statement of his monograph on the tintinnid ciliates of the last cruise of the Carnegie (Campbell 1942), thanking his wife for being 'an invaluable assistant in many ways'. We do not know if had any children or has any living relatives.

\section{Academic Career}

Arthur Campbell's academic career can only be imperfectly pieced together from diverse sources: affiliations given in his publications, acknowledgements in publications by others, information published in records from the University of California, and from a newspaper article. He attended Pomona College, in Southern California from at least 1920, as his first publication dates from 1920 in the college's journal, the Journal of Entomology and Zoology (Sup Ref: Campbell 1920). Campbell graduated in 1921 with a Bachelor's degree from Pomona College according the records of the University of California (Sup Ref: Anon. 1926a). In 1922-1923 he was a faculty member of the Canton Christian College in southern China according to a publication on Chinese Molluscs (Sup Ref: Campbell 1923), as well as acknowledgements from those to whom he sent specimens from China of echinoderms (Sup Ref: Fisher 1922) and a polychaete (Sup Ref: Chamberlain 1924). In July of 1923 he returned to California as he was granted a Thayer Fellowship (Sup Ref: Anon. 1923), allowing him to attend Harvard from 1923 to 1924. Records of the University of California for 19251926 (Sup Ref: Anon 1926a) indicate that Campbell graduated with an M.A. in 1924 from Harvard, but make no mention of what he studied at Harvard; the record lists him as a Ph.D. candidate and teaching assistant in the Department of Zoology at the University of California (Berkeley, CA USA) in 1925. The Register's report of the University of California for 1926-1927 (Sup Ref: Anon 1926b) lists Campbell as having completed his Ph.D. with the thesis entitled "The cytology of Tintinnopsis nucula (Fol.) Laachmann with an account of its neuromotor system, division, and a description of a new intra-nuclear parasite" without, however, specifying the year his degree was awarded as 1926 or 1927 . We know that his Ph.D. supervisor was Charles Kofoid.

Arthur Campbell's first academic appointment, outside of the University of California, may have been as a faculty member at Saint Mary's College in 1926. According to an article, apparently based on an interview with Campbell (Sup Ref: Anon. 1926c), in the Oakland Tribune, a daily newspaper, Campbell is said to be "staff member of the University of California and Saint Mary's College". The short article concerning his Ph.D. work, reproduced in Figure 1, is remarkable as an early effort of scientific outreach to the general public and very likely the first (and perhaps only) article in a daily newspaper focused on tintinnid ciliates. Although described as a staff member of Saint Mary's in 1926 in the newspaper article, it is unclear when he actually took up residence at Saint Mary's. 


\begin{tabular}{l} 
HOME BUILDING \\
RECORD IS HELD \\
BY SEA ANIMAL \\
Tiny Creature Propagates by \\
Dividing Itself in \\
$\quad$ Halves \\
BERKELE, Nov. 12 -Could \\
Bou build yourself a home in two \\
minutes? \\
Such a feat is a common occur- \\
rence in the life of tintinnopsis \\
nocula, a sea animal as tiny as'to \\
be invisible to the naked eye, con- \\
cerning which Arthur S. Campbell, \\
staff member of the zoology de- \\
partment of the University of \\
California and St. Mary's College, \\
has just made some unusual dis- \\
coveries. \\
'In spite of its size, this animal, \\
one of millions of varieties which \\
are found, floating in the oceans of \\
the world, has a nerve center or \\
brain spot more complex than that \\
of a bee, and can build itself a \\
house in something less than two \\
two minutes flat, says Campbell. \\
Campbell is the first scientist to \\
make a detailed study of the tintin- \\
nopsis. Its existence having only \\
been noted before by two foreign \\
savants. His research was made \\
from specimens found in San \\
Francisco bay. There he found a \\
new species somewhat different \\
from previous discoveries and \\
seemingly native to California \\
which he has named 'tintinnopsis \\
neriticus'. \\
The microscopic shells of the \\
animals are remarkably delicate \\
and beautiful, according to Camp- \\
bell's description. They resemble \\
vases or earthenware pots, and are \\
often decorated with flutings and \\
projections of exquisite architect- \\
-ure. \\
'The animal reproduces by di- \\
viding in half, and the daughter \\
organism, as it is called, is left in \\
possession of the old shell, while \\
the other half builds itself a new shelll \\
Campbell declares. 'Thus \\
the old shell is passed on as an \\
inheritance.' \\
\hline
\end{tabular}

Figure 1. Reproduction of an article published in the Oakland Tribune on November 14, 1926, (Sup Ref: Anon. 1926c) apparently based on an interview with Arthur Campbell. The article is likely the first on tintinnid ciliates published in a daily newspaper. 
The first article Arthur Campbell published after his Ph.D. studies concerned a plankton collecting device published in the March 23 issue of Science (Campbell 1928). He gave his affiliation as San Bernardino Valley Union Junior College. The first publication with a Saint Mary's College affiliation was an abstract from the December 1928 meeting of the Society of Zoologists (Sup Ref: Campbell 1929). Most of Campbell's subsequent publications gave his affiliation as Saint Mary's College. However from 1951 onward, some articles listed an affiliation as also with the University of California. In his last publication (Campbell \& Holm 1957) he listed his affiliation as "Protozoologist, Saint Mary's College of California and Museum of Paleontology, University of California, Berkeley, Calif."

\section{Scientific Contributions}

Arthur Campbell's scientific research stretched across nearly 4 decades and concerned a wide variety of taxa. This can be seen in Figure 2 that shows an early portrait and a "word cloud" from the titles of his 38 publications; the supplementary file contains a complete listing of his publications. His early work was conducted while he was an undergraduate at Pomona College. His first published study was on the nervous system of a centipede (Sup Ref: Campbell 1920). He then apparently benefitted from the Pomona College's Marine Station in Laguna Beach (CA, USA) as he published on echinoderms (Sup Ref Campbell 1921a,b,c; 1922a), and hydroids (Sup Ref: Campbell 1922b), signing his papers, all published in the College's Journal of Entomology and Zoology, as 'Contribution from the Laguna Marine Laboratory of Pomona College'. Campbell's first paper after leaving Pomona College for the Canton Christian College was also on invertebrates, "Some Common Chinese Mollusca", and was also published in the Journal of Entomology and Zoology but with affiliation "the Zoological laboratory and Museum of the Biological Survey of South China, of Canton Christian College" (Sup Ref: Campbell 1923).
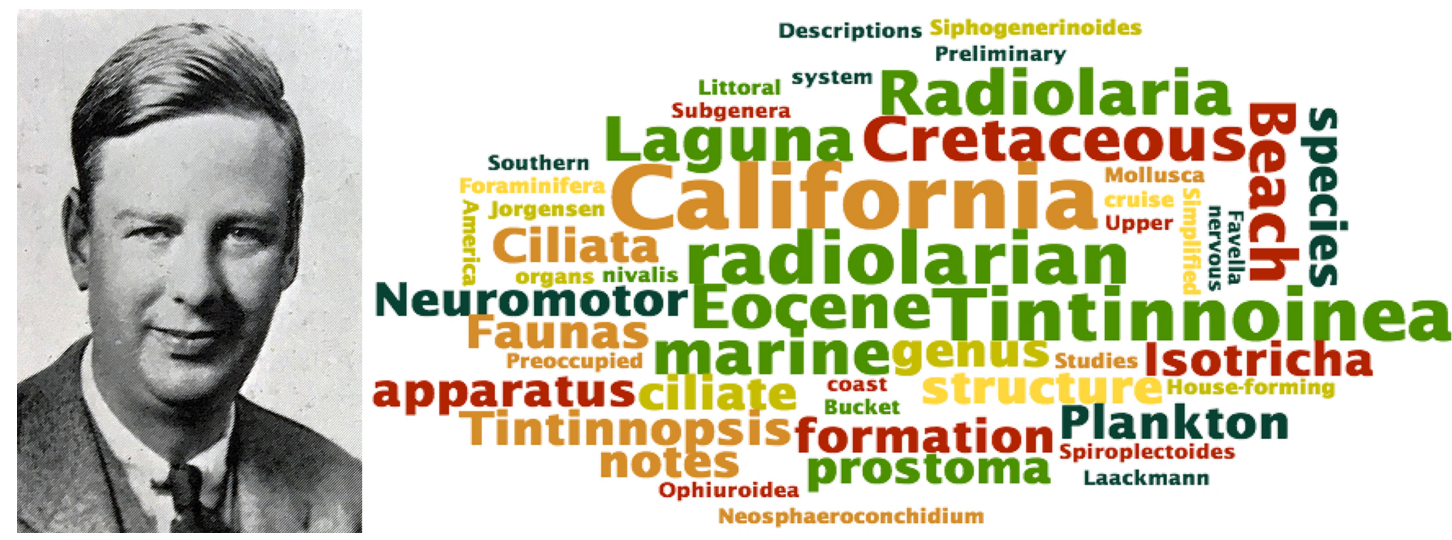

Figure 2. Arthur Campbell, circa 1929, pictured in an early yearbook of Saint Mary's College (courtesy of Brother Charles Wilkins) and a 'word cloud' of terms from the titles of all of Campbell's publications (1920 to 1957). The size of words shown is indicative of their frequency of occurrence. 
Moving to Berkley, Arthur Campbell's focus shifted to protists. His Ph.D work, under the direction of Charles Kofoid at the University of California, was on tintinnid ciliates. Like many of Kofoid's students, he appears to have spent considerable effort in documenting the existence of the now de-bunked ciliate 'neuromotor system', supposed to be a sort of protistan nervous system of fibers joined by a central 'neuromotorium' that governed and coordinated the activity of cilia. It was first described by Kofoid's student Robert Sharp in the rumen ciliates Diplodinium eucaudatum (Sup Ref: Sharp 1914). All of Kofoid's students following Sharp who worked on ciliates appear to have been obliged to describe it. Campbell's efforts can be seen in the title of his thesis, "The cytology of Tintinnopsis nucula (Fol.) Laachmann with an account of its neuromotor system, division, and a description of a new intra-nuclear parasite"; the 1926 newspaper article shown in Figure 1 which mentions a tintinnid brain spot more complex than the brain of a bee, and Campbell's 1927 article "Studies on the marine ciliate Favella (Jorgensen), with special regard to the neuromotor apparatus and its role in the formation of the lorica" (Sup Ref Campbell 1927). Various actual structures, such as a ventral kinety (see Fig. 3), were identified as components of the apparatus. The existence of a neuromotor apparatus in ciliates was finally laid to rest with advent of Transmission Electron Microscopy (Sup Ref: Pitelka 1970).

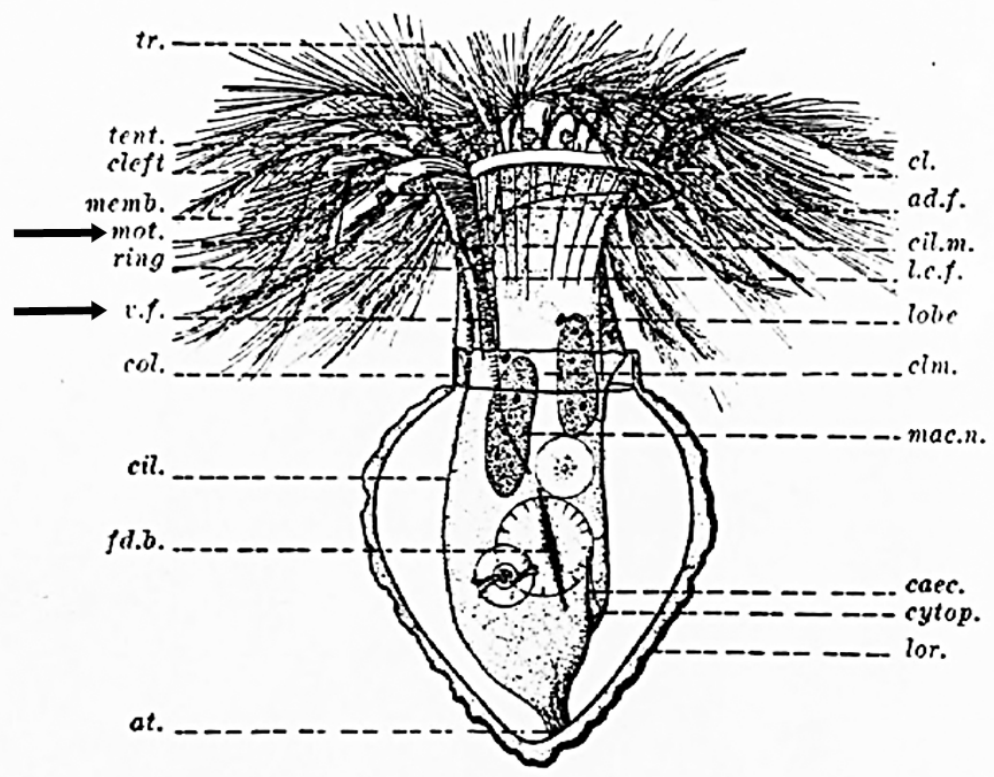

Fig. B. Semidiagrammatic figure of Tintinnopsis shorsing the general mor. phology of the cytosome. Abbreviations: ad.f., adoral fiber of the neuromotor apparatus; at., attachment to the lorica ; caec., caecum ; cil., somatic cilia ; cil.m., ciliary membrane; cl., peristomal collar; clm., column; cleft, cleft in the peristomal margin; col., lorical collar; cytop., cytopyge; fd.b., food body; lobe, lateral column lobe used in shell-building; lor., outlines of the lorica; l.c.f., lateral ciliary field; mac.n., macronucleus; memb., membranelle; mot., neuromotorium; ring circumoesophageal ring; tent., tentaculoid; tr., trichocysts; 2 .f., rentral fiber of the neuromotor apparatus. $\times 850$.

Figure 3. An illustration of cellular structures of Tintinnopsis from Campbell's Ph.D. thesis work, published in Campbell 1926. Note the identification of a 'neuromotorium' (mot.) and a ventral kinety (v.f.) identified as as a 'ventral fiber of the neuromotor apparatus'. 
The first well-known works of Arthur Campbell, still regularly cited today, are the Kofoid \& Campbell monographs on tintinnid ciliates. The first (Kofoid \& Campbell 1929) is a 403 page monograph entitled "A Conspectus of the Marine and Freshwater Ciliata Belonging to the suborder Tintinnoinea, with Descriptions of New Species Principally from the Agassiz Expedition to the Eastern Tropical Pacific 1904-1905". In 1939 a second, 473 page monograph appeared (Kofoid \& Campbell 1939) with more detailed descriptions of the species from the Agassiz Expedition and a revision and re-organization of many tintinnid taxa. It was one of the many reports of the Agassiz Expedition to the Eastern Tropical Pacific.

With regard to the two tintinnid monographs published with Kofoid, it is difficult to assess Arthur's Campbell's role as second author. Did he work as an equal or an assistant to Kofoid? Obviously we cannot know for certain. However, the tintinnid monographs differed considerably from Kofoid's three other large monographic works, all on dinoflagellates, with regard to the expertise of his second author. Campbell was a bona fide expert on tintinnids; he had published as much on tintinnids as Kofoid himself. By 1929, Campbell had published 3 articles on tintinnids (Sup Refs: Campbell, 1926a,b; 1927) as had Kofoid according to Goldschmidt's memoir on Kofoid (Sup Ref: Goldschmidt 1951). In contrast, all three of the second authors of Kofoid's dinoflagellate monographs had no apparent expertise with regard to dinoflagellates prior to publishing with Kofoid. Olive Swezy of Kofoid \& Swezy 1921 (Sup Ref: Kofoid \& Swezy 1921) was a parasitologist, Tage Skogsberg of Kofoid and Skogsberg 1928 (Sup Ref: Kofoid \& Skogsberg 1928), was an ostracod taxonomist, and Alastair Adamson of Kofoid \& Adamson 1933 (Sup Ref: Kofoid \& Adamson 1933) was a graduate student at the University of California in entomology. Neither Skogsberg nor Adamson published further on dinoflagellates or with Kofoid. Only Olive Swezy continued to publish with Kofoid but on parasites (Sup Ref: Goldschmidt 1951). It appears plausible that Kofoid and Campbell could have interacted as peers in producing the tintinnid monographs, perhaps unlike the second authors of Kofoid's dinoflagellate monographs.

In the 1929 monograph no description appears of the contributions of the authors except a statement that the senior author (Kofoid) collected some material while traveling on steamers. In the 1939 monograph, clear statements are made in the Acknowledgements concerning Campbell's apparently considerable contribution, and are given below:

"The junior author has utilized his research time and his vacations from his obligations as Professor of Zoology in St. Mary's College, California, for the revision of the senior author's first draft of the manuscript of all families except the Undellidae and the Tintinnidae, and for the preparation of the first draft of the manuscript of those families.

Both authors have collaborated in the revisions which have arisen from new viewpoints of systematic relationships, the recognition of structures of greatest systematic value, the detection of areas of 
greatest environmental modification, and clearer concepts of generic and specific characters and limits. The senior author has revised and condensed the second draft to its present form."

According to the publication date, the 1939 Kofoid \& Campbell was the second of Arthur Campbell's monographs on tintinnids. Campbell's third and last monograph on tintinnid ciliates, "The Oceanic Tintinnoina of the Plankton Gathered during the Last Cruise of the Carnegie", of 134 pages, with Campbell as sole author, appeared in 1942 (Campbell 1942). The last cruise of the Carnegie had ended many years before, and famously, with the explosion of the ship in November of 1929, about halfway through the planned expedition, while re-fueling in Somoa. The blast killed J.P. Ault, the Captain and Chief Scientist. None of the samples were lost as they had been periodically off-loaded and shipped back to Washington D.C. However, the death of the chief scientist left the exploitation of the expedition results to J. A. Fleming, Director of the Department of Terrestrial Magnetism at the Carnegie Institution of Washington D.C., and he had neither oceanographic nor biological training.

Exactly how Campbell got involved with working up the Carnegie samples, and when he started working on them is unclear. Many researchers of renown (Albert Mann, Henry Bigelow, etc.) were mentioned as interested in, or working on, biological samples from the last cruise of the Carnegie in the Carnegie Institution Yearbooks from 1931 onward (Sup Ref: Anon. 1931, 1932, 1933, 1934, 1935). However, the first mention of Campbell is in the 1936 Yearbook which states that Campbell had made good progress in his investigations and would soon be submitting his report (Sup Ref: Anon. 1936), an apparently accurate statement as the tintinnid monograph was completed and submitted in 1937 (Sup Ref: Anon. 1937). Unfortunately, publication was delayed until another monographic work, on dinoflagellates by Herbert Graham, was finished. Although likely of little consolation, Campbell's 5 year wait was not the longest an author had to wait to see his worked published. Charles B. Wilson's monograph on the copepods of the Last Cruise of the Carnegie had been submitted in 1933 (Anon. 1933) and it also appeared in 1942, one year after Wilson's death.

Arthur Campbell's Carnegie monograph represented a very substantial amount of work. He examined 648 samples from the 165 stations sampled during the cruise throughout the Pacific Ocean and the North Atlantic. Most of the samples, 560, contained tintinnid material. He found 307 species in the Carnegie material including forms he designated as new species (Fig. 4). In comparison, the Kofoid \& Campbell 1939 monograph on the tintinnids of the Albatross Expedition to the South Pacific was based on the examination of 174 samples from 130 stations. The 1939 monograph, stated as having been in preparation from at least 1911, reported on 347 species, 25 of which were described as new, numbers quite comparable to those of Campbell's Carnegie monograph. 


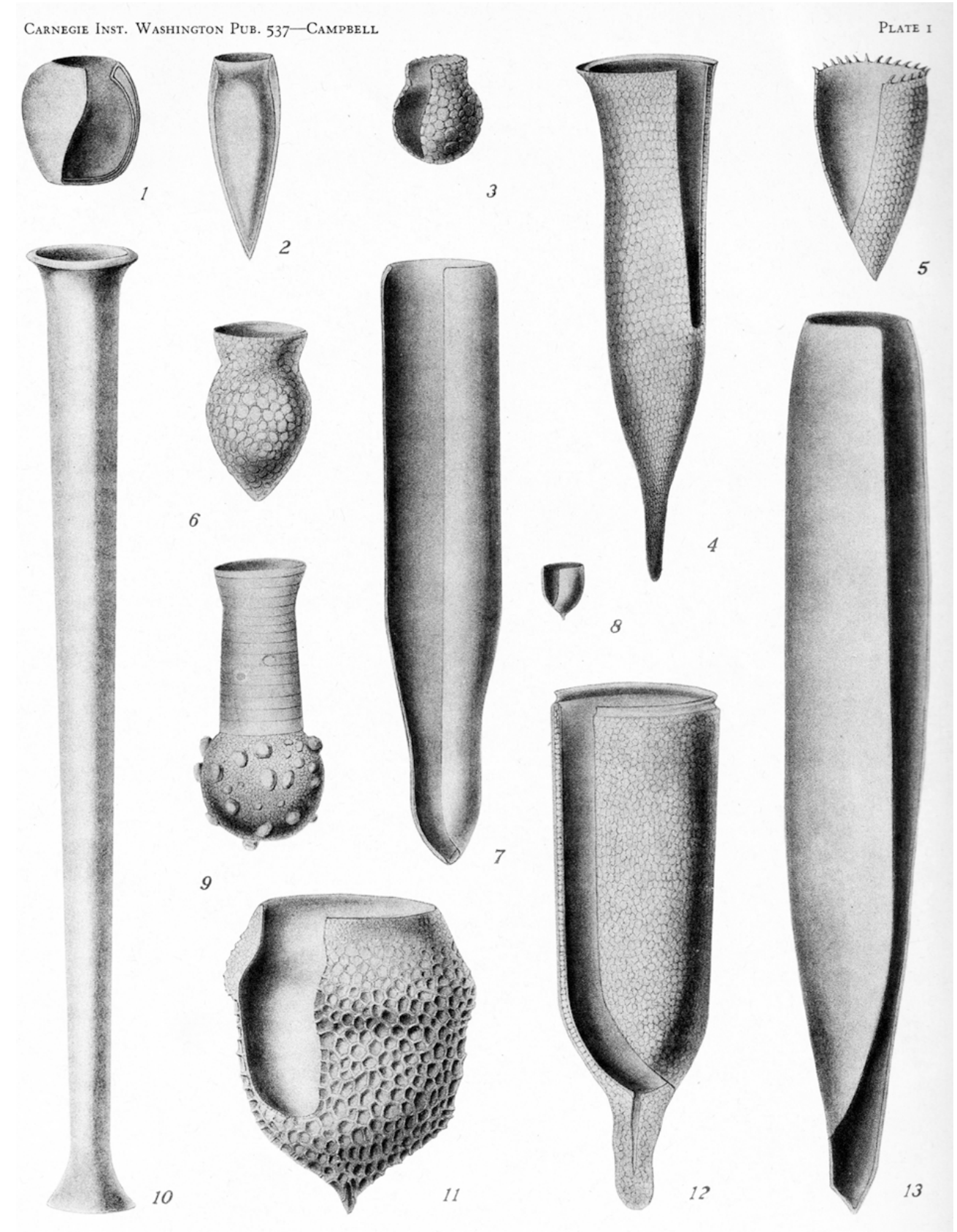

Figure 4. The Plate from Campbell's 1942 monograph "The Oceanic Tintinnoina of the Plankton Gathered during the Last Cruise of the CARNEGIE" showing forms he described as new species.

Well before his last two monographic works on tintinnids appeared in print, Campbell had already turned his attention to microfossils. By 1933 Campbell was communicating with Joseph A. Cushman, director of the Cushman Foundation for Foraminiferal Research and author of "Foraminifera; their classification and economic use" (Sup Ref: Cushman 1928). Cushman helped establish the value of microfossils in identifying geological strata (Sup Ref: Henbest 1952). The Cushman Archives lists letters and exchanges of material from 1933 to 1941. 
Campbell and Cushman published 4 papers, all on fossil foraminifera from deposits in California, all authored as Cushman \& Campbell (Sup Ref: Cushman \& Campbell 1934,1935,1936,1943).

Campbell began a shift from fossil foraminifera to fossil radiolaria by the early 1940 's, working with Bruce L. Clark of the Paleontology Department of the University of California, Berkeley. Clark was described as an outstanding authority on invertebrate paleontology and like Campbell, an alumnus of Pomona College (Sup Ref: Camp 1946). Clark's expertise was molluscs, not protists. Campbell and Clark produced four substantial monographs on fossil radiolaria. In the first monograph on Eocene radiolaria from the Mt. Diablo Area (Sup Ref: Clark \& Campbell 1942), it is stated that Clark was responsible for the geology, some of the general conclusions, and served as critic in connection with problems of taxonomy. Campbell was said to have been responsible for the descriptive and taxonomic work, the bulk of the monograph, representing 81 of the 93 text pages. The three later monographs, on the Miocene radiolaria from Southern California (Campbell \& Clark 1944a), radiolaria from the Upper Cretaceous of Middle California (Campbell \& Clark 1944b and on radiolaria from the Kreyenhagen formation near Los Banos, California (Sup Ref: Clark \& Campbell 1945), contained no information on author contributions but all three greatly resembled the first monograph in that following a short introduction on the geological context of the samples, the bulk of the monographs consist of descriptive and taxonomic text on radiolaria. It would seem reasonable to attribute the taxonomic and systematic work in all three monographs to Arthur Campbell. Collectively, the four monographs contain descriptions and images of 360 spumellarian and nassularian forms, described as new fossil species (for examples, see Figure 5). Campbell is among the most prolific authors of new radiolarian species, in seventh place, after Haeckel, Kozur, Mostler, Ehrenberg, Pessagno and Dumitrica (Lazarus et al. 2021). Bruce Clark died in September of 1945, leaving Arthur Campbell as the authority on fossil radiolaria in North America. Until his retirement, Arthur Campbell worked nearly exclusively on fossil radiolaria. 


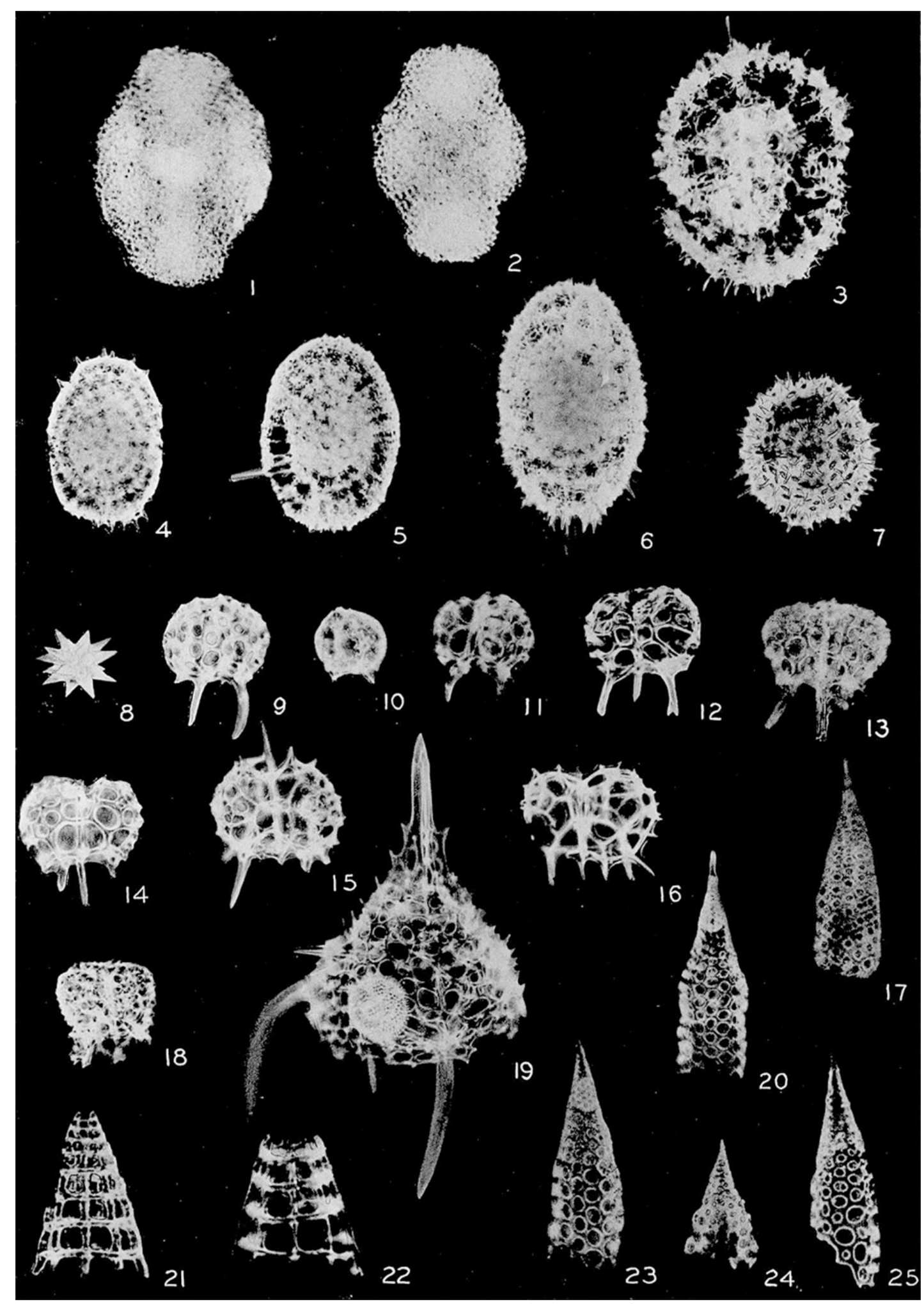

Figure 5. Plate from Campbell \& Clarks's 1942 monograph " Miocene Radiolarian Faunas from Southern California" (Campbell \& Clark 1942a).

From 1951 to 1957 Campbell published 6 articles on fossil radiolaria, 5 as first author. The articles ranged from general to more specialised taxonomic works, 
for example 'New genera and subgenera of Radiolaria' (Sup Ref: Campbell 1951) and 'An introduction to the study of Radiolaria' (Sup Ref: Campbell 1952). The articles, as well as the protist book chapters, "Radiolaria" and "Tintinnina" (Campbell 1954) in Moore's 'Treatise on Invertebrate Paleontology' indicate that Campbell was indeed the authority on fossil radiolaria in North America. However it should be noted Campbell's revision of Haeckel's taxonomy in Campbell 1954 has been widely ignored (Lazarus et al. 2021). While Campbell authored fewer publications, and very many fewer pages on radiolaria than he did on tintinnids, he finished his career as an authority in his own right on radiolaria.

Arthur Campbell's co-authors, Kofoid, Cushman, and Clark are recognized today as important figures. For example, both Kofoid and Cushman were featured in Corliss's 1978 "Salute to 54 great microscopists of the past". Campbell though appears to have been largely forgotten. He has received but meager recognition. A genus of tintinnid ciliates, Ascampbellelia, was named after him to replace a previously occupied generic name (Sup Ref: Corliss 1960) and a species of fossil radiolarian, Spongosaturnalis campbelli (Sup Ref: Foreman 1968) was named in his honour. . Hopefully, this essay will serve as evidence that Arthur Campbell, best known as second author to famous figures, made substantial contributions to protistology.

\section{References}

Campbell AS (1926) The Cytology of Tintinnopsis nucula (Fol) Laackmann: With an Account of Its Neuromotor Apparatus, Division, and a New Intranuclear Parasite. Univ Calif Pub Zool 29:179-236

Campbell AS (1928) A Simplified plankton bucket. Science 67:322

Campbell AS 1942. The oceanic Tintinnoinea of the plankton gathered during the last cruise of the Carnegie. Carnegie Institution of Washington Publication 537, Carnegie Institution, Washington, D.C.

Campbell, A. S. (1954). Protozoa. in Moore RC (ed) Treatise on Invertebrate Paleontology, Part D Protista 3. Protozoa (Chiefly Radiolaria and Tintinnina), D11-D180, Boulder, C0: Geological Society of America

Campbell AS, Clark BL (1944a). Miocene Radiolarian Faunas from Southern California. Geological Society of America Special Papers Number 51

Campbell AS, Clark BL (1944b) Radiolaria from the Upper Cretaceous of Middle California, Special Papers Geological Society of America, No. 57

Campbell AS, Holm EA (1957) Radiolaria. Geological Society of America Memoirs, 67:737-744

Kofoid CA, Campbell AS (1929) A Conspectus of the Marine and Freshwater Ciliata Belonging to the suborder Tintinnoinea, with Despcriptions of New 
Species Principally from the Agassiz Expedition to the Eastern Tropical Pacific 1904-1905. Univ Calif Pub Zool 34:1-403

Kofoid CA, Campbell AS (1939) Reports on the scientific results of the expedition to the Eastern Tropical Pacific, in charge to Alexander Agassiz, by U.S. Fish Commission Steamer "Albatross". from October 1904 to March 1905, Lieut. Commander L.M. Garrett, U.S.N. commanding. 37. The Ciliata: The Tintinnoinea. Bull Mus Comp Zool, Harvard 84:1-473

Lazarus D, Suzuki N, Ishitani Y, Takahashi K, eds (2021) Paleobiology of the Polycystine Radiolaria. Wiley Blackwell, Hoboken, 481 p

\section{Acknowledgements}

The comments and suggestions of the Monitoring Editor, Barry Leadbeater, and the anonymous reviewers led to significant improvements in the text. However, I retain full responsibility for all errors of fact, omission, and interpretation.

\section{Supplementary Data}

Supplemental References and an Arthur S. Campbell bibliography are provided in the online version at ' $\mathrm{xxxx}$ ' 